\title{
Crumb Rubber in Concrete-The Barriers for Application in the Construction Industry
}

\author{
Patricia Kara De Maeijer ${ }^{1, *(\mathbb{C}, \text { Bart Craeye }}{ }^{1,2}$, Johan Blom ${ }^{1}\left(\mathbb{C}\right.$ and Lieven Bervoets ${ }^{3}$ \\ 1 EMIB, Faculty of Applied Engineering, University of Antwerp, Groenenborgerlaan 171, \\ 2020 Antwerp, Belgium; bart.craeye@uantwerpen.be (B.C.); johan.blom@uantwerpen.be (J.B.) \\ 2 DuBiT, Department of Industrial Sciences \& Technology, Odisee University College, 9320 Aalst, Belgium \\ 3 SPHERE, Department of Biology, University of Antwerp, Groenenborgerlaan 171, 2020 Antwerp, Belgium; \\ lieven.bervoets@uantwerpen.be \\ * Correspondence: patricija.karademaeijer@uantwerpen.be
}

Citation: Kara De Maeijer, P.; Craeye,

B.; Blom, J.; Bervoets, L. Crumb

Rubber in Concrete-The Barriers for

Application in the Construction

Industry. Infrastructures 2021, 6, 116

https://doi.org/10.3390/

infrastructures6080116

Academic Editor: Kamil

Elias Kaloush

Received: 23 July 2021

Accepted: 17 August 2021

Published: 20 August 2021

Publisher's Note: MDPI stays neutral with regard to jurisdictional claims in published maps and institutional affiliations.

Copyright: (c) 2021 by the authors. Licensee MDPI, Basel, Switzerland. This article is an open access article distributed under the terms and conditions of the Creative Commons Attribution (CC BY) license (https:// creativecommons.org/licenses/by/ $4.0 /)$.

\begin{abstract}
This state-of-the-art review was aimed to conduct a comprehensive literature survey to summarize experiences of crumb rubber (CR) application in concrete within the last 30 years. It shows that certain gaps prevent obtaining a coherent overview of both mechanical behaviour and environmental impact of crumb rubber concrete (CRC) to object to the stereotypes which prevent to use of CR in concrete in the construction industry. Currently, four major barriers can be distinguished for a successful CR application in the concrete industry: (1) the cost of CR recycling, (2) mechanical properties reduction, (3) insufficient research about leaching criteria and ecotoxicological risks and (4) recyclability of CRC. The application of CR in concrete has certainly its advantages and in general cannot be ignored by the construction industry. CR can be applied, for example, as an alternative material to replace natural aggregates and CRC can be used as recycled concrete aggregates (RCA) in the future. A certain diversity for the CR application can be introduced in a more efficient way when surface treatment and concrete mix design optimization are properly developed for each type of CR application in concrete for possible field applications. The role of CRC should not be limited to structures that are less dependent on strength.
\end{abstract}

Keywords: crumb rubber (CR); crumb rubber concrete (CRC); mechanical properties; durability; leaching; ecotoxicology; recyclability

\section{Introduction}

One billion end-of-life tires (ELTs) are generated globally each year, 355 million of ELTs out of this production are related to the EU [1,2]. The majority of ELTs are landfilled and only about $5 \%$ is used for civil engineering applications. However, considering the massive requirement for construction (approximately 32 billion tons each year [3]), the application of crumb rubber (CR) as a recycled organic component in Portland cement concrete can effectively resolve the environmental pressures [4] and has the potential to abate the consumption of virgin materials while simultaneously reducing landfill dumping [5].

The use of ELTs as CR aggregates (coarse and fine granulates) in the construction industry has been intensively studied in several countries [6-9]. Several researchers referred to the decrease of the mechanical properties of rubberized concrete, some researchers reported the enhancing of the properties of the CR particles by means of pre-treatment of CR surface to be compatible with cement matrix, but less information was provided regarding $C R$ hazardous impact to the environment and how to mitigate it.

The outcome of experimental programs showed that there are certain gaps that prevent to obtain a coherent overview of both mechanical behavior and environmental impact of crumb rubber concrete (CRC) to object the stereotypes which prevent to use CR in concrete in the construction industry. 
The current definition of the gaps in research and market indicates certain barriers or stereotypes which limit the application of CR in the construction industry. Those could be listed as follows:

- The current construction materials market is rather conservative and there is a need to foresee the alternative solutions since natural aggregates resources are depleting [10];

- Constant flow of available materials and their storage, efficient time frame for the delivery of the materials within the country/countries (for example, secondary streams are very important). Meanwhile, the cost for natural aggregate keeps increasing due to the limited source and long transport distance [5];

- $\quad$ CRC cost analysis and comparison to the traditional concrete vary from country to country due to the limited industrial-scale production of CR [11]. The price of CR ranges from 40 to 320 EUR per ton based on its origin and fineness;

- The end-of-waste (EoW) management is crucial, and recycling is mandatory; however, the profit of recycling is limited by the manufacturing costs; also, it depends on the recycling developments within the countries (which may differ quite a lot from country to country);

- Society reaction to waste usage in construction materials due to lack of sufficient technical information and comprehension may develop certain barriers in application of different recycled materials;

- The recycled rubber products have poor mechanical performances-interfacial bond strength as the main factor which limits the application of CR in construction elements;

- Insufficient investigation of leaching behavior and ecotoxicological impact to the environment;

- Insufficient information on the recyclability of concrete containing CR;

- For the moment, there are no restrictions defined regarding CR application in concrete nor rubberized concrete aggregates.

In 2016, yearly global production of natural and synthetic rubber reached 27.3 million tons (54\% synthetic), with $\sim 70 \%$ used in the manufacture of vehicle tires. It has been recorded that around 1 billion tires are discarded every year and this number may increase up to 1.2 billion by the end of 2030 [12,13]. Tire manufacturing is a global business: there are over 160 tire manufacturers located in more than 45 countries worldwide. Tires are made to international standards and are freely traded across the world. Not each country might have natural resources for construction, but it has tires disposal. Stockpiling of used tires is very common in several countries that leads, in general, to a serious ecological threat contributing to the reduction of biodiversity since the tires also contain toxic and soluble components [14]. Tire materials are complex mixtures; as various chemicals are used during the production of tires. Tires contain a total of approximately $1.5 \%$ by weight of potentially hazardous waste compounds: copper $(\mathrm{Cu})(0.02 \%)$, zinc $(\mathrm{Zn})(1 \%$, but can be up to $2 \%)$, cadmium $(\mathrm{Cd})(\max 0.001 \%)$, lead $(\mathrm{Pb})$ and $\mathrm{Pb}$ compounds (max $0.005 \%$ ), acidic solutions $(0.3 \%)$. Despite consistent usage of the general ingredients, the composition of a specific tire depends on its application. For example, a common-sized all-season passenger commercial tire contains approximately 30 types of synthetic and 8 natural rubbers, 8 kinds of carbon black, steel cord for belts, polyester and nylon fiber, steel bead wire and 40 different chemicals, waxes, oils, pigments, silica and clays [15-17]. One of the suggested compositions can be taken as a reference [18]: rubber/elastomers (48\%), carbon black $(22 \%)$, metal $(15 \%)$, additives $(8 \%)$, textile $(5 \%)$, zinc oxide $(1 \%$-passenger tires or $2 \%$ truck and off-road tires), sulphur (1\%). 
The ELTs are generally disposed of in different ways such as burning, landfilling and use as fuel. The burning of tires causes serious fire hazards, emission of potentially harmful compounds, landfilling by ELTs results in depletion of the available useful sites. The use of ELTs as fuel is economical but not attractive when compared to other products used for the same purpose.

According to European Community Directives [19,20], ELTs are banned from landfills due to the risk of pollutant release. The production of crumb rubber granulates (CRG) from ELTs has been considered as an acceptable way of utilizing this recycled waste material. However, according to Directive 2008/98/EC [20], the specific EoW criteria for CR are not defined. In general, there is a priority order for the EoW management which includes: prevention, preparation for re-use, recycling, recovery, and disposal.

In the EU the European Committee for Standardization (CEN) has classified products obtained from grinding of waste tires according to their size [21]. Particularly, the following five classes are defined:

- Cut tires, with size bigger than $300 \mathrm{~mm}$,

- Shreds, with size ranging between 20 and $400 \mathrm{~mm}$,

- Chips, with size ranging between 10 and $50 \mathrm{~mm}$,

- Rubber granulates, with size ranging between 0.8 and $20 \mathrm{~mm}$,

- Rubber dust, smaller than $0.8 \mathrm{~mm}$ (limited application, but can be successfully used in concrete).

In the last years, the suitability and efficiency of using different by-products (mainly steel fibers-used as a partial or total replacement of industrial steel fibers to produce Fiber Reinforced Concrete (FRC) [22-30] and rubber particles-used as a partial replacement of natural aggregates for producing rubberized concrete [31-36]) obtained from the recycling of waste tires for improving some concrete properties have been investigated, however, the related research is limited and leaves a wide space for further investigations [37].

With regards to the terminology, the most common frequently used terms for this type of concrete are rubberized concrete [38,39] and crumb rubber concrete (CRC) [40,41].

Mechanical shredding (particle size of 13-76 mm) and mechanical grinding (particle size $0.075-4 \mathrm{~mm}$ ) at ambient temperature, cryogenic grinding (particle size $0.18-1.4 \mathrm{~mm}$ ) particle size at a temperature below the glass transition temperature $\left(-200{ }^{\circ} \mathrm{C}\right)$, highpressure waterjet grinding (particle size $0.2-1 \mathrm{~mm}$ ) are the technologies used to obtain rubber aggregates. The Scanning Electron Microscope (SEM) images of CR particles are shown in Figure 1a-c. Mechanical shredding tends to produce rough-edged particles with many hair-like appendages, along with generated heat rubber particles get aged and rubber properties are altered, the fibers are removed with an air separator and the metal with magnets. Cryogenic processing has the advantage of not generating heat throughout the process and the CR produced has little fiber and metal content. Waterjet processing under the impact of the water stream leads to micro-blasting of the rubber and directly separates the rubber from the steel belt, further wet slurry undergoes separation in a centrifuge [42]. 


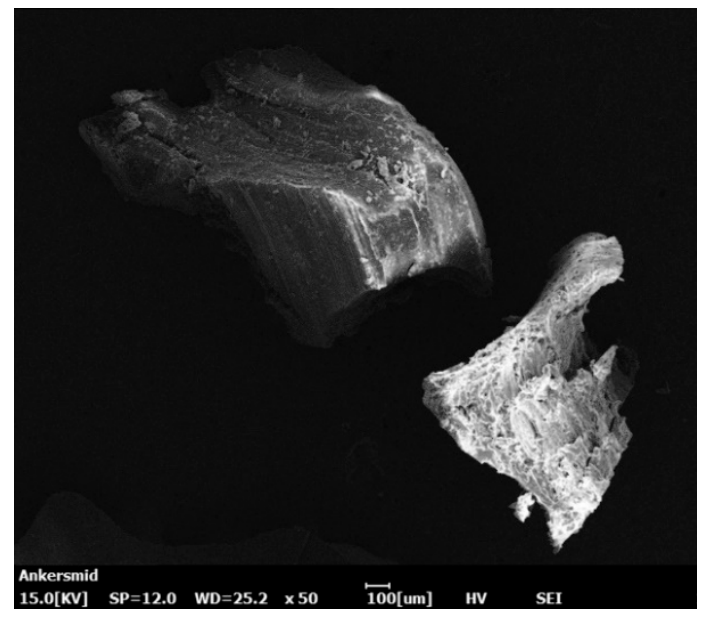

(a)

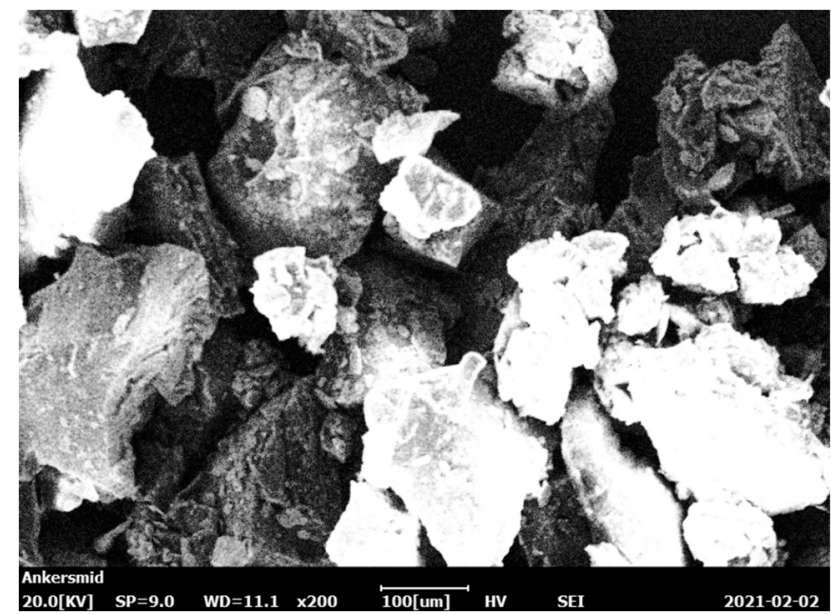

(b)

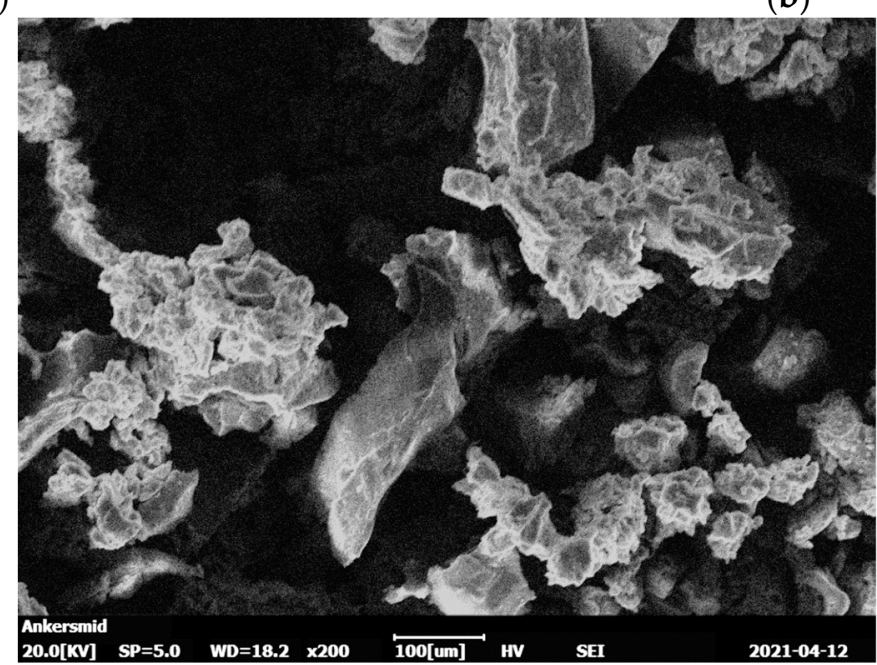

(c)

Figure 1. SEM images of the CR particles at $100 \mu \mathrm{m}$ scale: (a) mechanical, (b) cryogenic and (c) waterjet.

\section{Review Significance}

2.1. CR application in Concrete in Large Research Projects

The tire recycling sector is constituted by large communities of small and mid-size enterprises (SMEs), estimated as more than 20,000 connected to the recycling trade in Europe. The sector is in a compelling need of looking for an innovative and decisive solution to increase the competitiveness of tires recycling. The rubberized concrete has the advantages of low density [43], good sound absorption [33], acid resistance [13,14], freeze-thaw resistance [44], chloride permeability resistance [45,46], increased damping capacity, bending impact strength and toughness [31,47-49]. These advantages make the rubberized concrete attractive for applications such as lightweight concrete [50-52], nonbearing concrete walls [53], noise screen [33,45,51], improved thermal insulation for flooring in buildings [54,55], reinforced concrete jersey barriers [38,56,57], pavement [38,58,59], railway track beds [60], reinforced column for earthquake-resistant structures [45,61,62], rubberized concrete beams with high impact resistance [63,64], expansion joints in the concrete floor [65], steel tubes filled with rubberized concrete [66,67]. These positive characteristics can be useful in supporting the development of sustainable CRC to achieve greater environmental and economic benefits.

Several international projects were carried out to utilize CR in concrete within the last decade. Among those the most successful are: SMART (7-FP, 2012-2015) [6], ANAGENNISI (7-FP, 2014-2017) [7], RISEN (H2020, 2016-2020) [8] and the Australian Research Council (ARC) Linkage project (2016-2020) [9]. These projects involved the following 
countries' contributions: Australia, Bosnia and Herzegovina, Croatia, Cyprus, Czech Republic, Finland, France, Germany, Italy, Norway, Poland, Portugal, Romania, Slovenia, Spain, Sweden, The Netherlands, and the UK. It was mentioned in the SMART project [6] that the added value of a recycled product derived from the tire-shredding process is very low due to the following factors: (1) the recycled rubber products have poor mechanical performances, (2) the profit of recycling is limited by the manufacturing costs. Within the ANAGENNISI project, several demonstration projects were undertaken in five European countries to convince contractors and infrastructure owners of the benefits of the examined tire by-products. Some projects included slabs on grade, tunnel linings, precast concrete elements (rubberized poles and railway sleepers [8], safety road barriers and a repair screed application [7]. Within the ARC Linkage project [9] reinforced concrete constructed with CR from used tires as a partial replacement for sand was a viable option for the construction of residential footing slabs that utilize approximately $40 \%$ of reinforced concrete poured in Australia each year.

\subsection{Mechanical Properties - The Main Barrier for Application in the Construction Industry}

The first patent invention related to rubber crumb reinforced cement concrete was filed by Frankowski [68] in 1992. There were several studies related to the application of $\mathrm{CR}$ in concrete performed in the $90 \mathrm{~s}[38,69-74]$. At that time, it was stated that rubberized concrete did not demonstrate brittle failure and had abilities to absorb a large amount of plastic energy under compressive and tensile loads, to improve shock wave absorption, to provide resistance to cracking, to be fire-resistant, to lower heat conductivity and to improve the acoustical environment (e.g., noise reduction barriers) which is advantageous in applications in structures subjected to dynamic and impact loading and non-structural elements [12]. According to statistics, about 70\% of the CR powder was used for construction engineering in the United States [65]. CRC was not widely adopted in the industry since then mainly due to its low compressive strength, however, its structural properties are still relatively unexplored $[36,75,76]$.

Topçu [77] assessed the brittleness index of rubberized concrete and concluded that concretes containing 15\% rubber chips by weight gave the highest brittleness index values with low compressive strength and toughness values. Bayomy and Khatib [38] examined the behaviour of rubberized concrete and concluded that it could be suitable for nonstructural purposes such as light-weight concrete walls, building facades, and architectural units. During the last two decades, there has been a significant growing interest in the use of recycled tire rubber in concrete and a significant number of scientific publications about CR in concrete were elaborated. In early 2000, a wave of pioneering effort to build CRC test sites was undertaken in the US on urban development-related projects [40]. Concrete designs of $11.9 \mathrm{~kg}$ up to $35.67 \mathrm{~kg}$ of CR per cubic meter were used in the construction of different types of concrete slabs. The building of these test slabs has provided very useful experience and the means to evaluate first-hand knowledge about CRC mixing, hauling, pumping, placing, finishing, and curing. Laboratory evaluation tests included compressive strength, thermal coefficient of expansion, fracture, shrinkage cracking and microscopic matrix analysis. The increased interest to recycle CR in different ways was observed in the late years of the last decade. There is an interest to find a solution for the application of $\mathrm{CR}$ in the concrete and asphalt industry looking for ways to increase the reactivity of this technogenic waste material to overcome the barriers which prevent the use of it in massive recycling in construction.

The use of tire rubber in concrete faces a challenge of lack of heat treatment, which is crucial to enable good adhesion between the tire rubber particles and other materials. Another challenge for this use lies in the potential mismatch in stiffness between the relatively soft viscoelastic rubber and the relatively rigid elastic cement-based matrix [78]. CR provides a corresponding improvement in concrete performance due to the flexibility of tire rubber aggregate, but its strength significantly decreases. Therefore, CRC has been primarily applied for concrete with low CR volume content (less than $20 \%$ of the total 
aggregate volume) and non-structural elements with lower bearing demand already in the $90 \mathrm{~s}[38,69]$. The experimental study was carried out by Hassanli et al. [79] to understand the behavior of CRC at the structural application level. It was concluded that increasing the CR content from $0 \%$ to $18 \%$ followed by the compressive strength reduction by $31 \%$ in concrete beams.

The affecting factors of strength loss due to the replacement of fine aggregates with CR have been reported in some studies. Eldin and Senouci [69] first discovered significant reductions in CRC strength through tests. When the rubber aggregates completely replaced the fine aggregates, the compressive and tensile strength of CRC decreased by $65 \%$ and $50 \%$, respectively. In addition, with the same rubber particle content of fine aggregate, the reduction rate of high-strength concrete was found to be greater than that of low-strength concrete $[36,39,80]$. The rubber type only has a marginal effect on the mechanical properties of CRC when the rubber aggregates replaced the fine aggregates. These results indicated that concrete containing rubber with fine grading had lower compressive strength than that containing rubber with coarse grading [35,38,71,72,81-85]. Because of its low modulus of elasticity, a piece of rubber aggregate acts as a large pore and does not have a significant role in the resistance to externally applied loads. Thus, the compressive and tensile strengths of concrete that contains rubber particles depend on the volume of rubber aggregate (fine and large pores) in concrete mass [81]. However, Bignozzi et al. [54] and Su et al. [4] reported that CRC with smaller CR particle size has higher compressive strength than that with larger CR particle size. In general, the replacement ratio of aggregates in rubber concrete should not exceed $20 \%$ of the total aggregates by volume [38].

Hassanli et al. [79] when studied the behavior of rubberized concrete at the structural application level, concluded that by increasing the rubber content from $0 \%$ to $18 \%$ followed by the compressive strength reduction by $31 \%$ in concrete beams, the strength reduction was only $6 \%$ and $12 \%$ in the corresponding tested beam and beam-column members, respectively. Valadares and de Brito [86] concluded that to avoid severe worsening of the mechanical properties of structural concrete the use of rubber coarse aggregates should be limited to percentage levels around $5 \%$ of the overall volume of aggregates. To minimize these negative impacts, however, one should opt for the coarser rubber aggregates since they unequivocally lead to more favourable performances, with the additional benefit of being cheaper to produce.

As mentioned above, compressive strength usually decreases with an increase of rubber content in rubberized concrete due to an increase in air voids and poor adhesion [36]. Flexural strength commonly decreases with the rubber percentage increase in concrete. Flexural strength of concrete was reduced up to $18 \%$ with $10 \%$ replacement of sand by CR and reached $32 \%$ with replacement of 50\% [87]. It was decreased by $9 \%$ and $19 \%$ when $10 \%$ and $15 \%$ CR was added as partial replacement of coarse aggregate [88]. The effect of rubber in concrete on split tensile strength (STS) is analogous to flexural strength behaviour, STS generally decreases for rubberized concrete with an increase of rubber percentage due to an increase in voids and poor adhesion [36]. STS was reduced from $16.5 \%$ to $31 \%$ when $5 \%$ to $40 \%$ fine aggregate replacement with CR was used [89]. As the rubber content increased, the indirect tensile strength (ITS) decreased but the strain at failure increased. A higher tensile strain at failure is indicative of a more ductile and a more energy-absorbent mix [40]. Elastic modulus decreases for rubberized concrete with an increase of rubber percentage when compared with the reference concrete due to low elastic modulus and poor bonding of CR [36]. The addition of CR from 5\% to $25 \%$ as partial replacement of fine aggregate, reduced the concrete elastic modulus by $2.44 \%$ to $31.74 \%$ [90]. For compressed CRC specimens, an increase in elastic modulus was noticed for specimens with a CR replacement ratio of up to 15\% [11,91]. CRC and reference concrete have a small difference in the key mechanical properties that affect bearing strength [66], such as properties under multi-axial compression, the ratio of tensile strength to compressive strength. This ultimately leads to the similar bearing strength of $\mathrm{CRC}$ and reference concrete when their compressive strengths are the same. 


\subsection{The Fresh Properties-Improvement of Workability}

The workability can be improved by the application of $\mathrm{CR}$ with particle fraction up to $1 \mathrm{~mm}$, the mix is getting nice consistency and easier for placing (with CR content up to $15 \%$ [92]). When CR is applied above $15 \%$ then fly ash [93,94], slag [95], metakaolin [96] are used to help to reduce viscosity. The study by Su et al. [4] demonstrated that with a $20 \%$ replacement ratio, the slump of the rubberized concrete can decrease from $13.7 \%$ to $25.2 \%$ based on the CR size. Rubber aggregates have the property to keep moisture away while attracting air on their rough surface which may results in more air voids when rubber content is increased in concrete [97]. The influence on air void for CR within 15\% replacement can be insignificant. CR can enhance workability by adjusting the aggregate gradation [98]. Adjusting the workability with a superplasticizer can also increase the air content [96].

The unit weight of the CRC mix decreased approximately $96 \mathrm{~kg} / \mathrm{m}^{3}$ for every $22 \mathrm{~kg}$ of CR added [40]. The density of the rubber is usually smaller than that of the water, the average density of the crumb rubber obtained is $870 \mathrm{~kg} / \mathrm{m}^{3}$ [99]. With the densities of the crumb rubber and the fine aggregate, the replacement of fine aggregates with crumb rubber for a certain replacement ratio by volume can be easily implemented using the density ratio between the fine aggregates and rubber, which is approximately 3 (i.e., $2580 / 870=2.97$ ). CR can be added as high as $40-50 \%$ of the aggregate volume without major workability problems [38]. CRC mixes can give a viable alternative to the normal weight concrete when the strength is not a major factor in the design, for example, with lightweight concrete walls, building façades or other building architectural units.

\subsection{Interfacial Bonding between the $C R$ Particles and Cement Matrix}

Khaloo et al. [33] noted that the reduced stiffness of rubber in relation to the other materials makes a minor contribution to global strength. Consequently, the rubber particles generate high stresses in their periphery which leads to cracking which, when widespread, causes premature rupture of the specimens. Topçu [71] explained this phenomenon based on the high tensile stresses in the direction perpendicular to loading. Therefore, the compressive strength reduction of CRC is mostly contributed by the difference of the elastic modulus between the $\mathrm{CR}$ and the cement matrix and the inadequate bonding between them. The elastic modulus of standard concrete is about 2.0-3.0 $\times 10^{4} \mathrm{MPa}$. This is about 30,000 times the elastic modulus of CRC which is about 0.5-2.0 MPa [100]. Under external load, the deformation of the rubber aggregates is much larger than that of the cement mix. The bonding between them is so weak that the rubber aggregates debond from the cement. The $\mathrm{NaOH}$ treatment, for example, can remove the dust on the rubber surface and improve the surface hydrophilicity leading to a denser Interfacial Transition Zone (ITZ) compared to the concrete with as-received aggregate [101,102]. If the bond is improved at ITZ by any suitable and economical means then the negative effects of $C R$ on strength properties of normal concrete may be reduced, consequently, it would be possible to effectively utilize the rubberized concrete in numerous concrete structures by the construction industry.

\subsection{CR Pre-Treatment}

Physical and chemical pre-treatment of CR can enhance interfacial bond strength in rubberized concrete. Although research studies have been done in this regard in the recent past, further research work is still required for the development of standard guidelines regarding the improvement of the bond between cement matrix and rubber aggregates. Literature review indicates that already investigated methods of bond improvement in rubberized concrete have resulted in improvement of compressive strength from $7 \%$ to $59 \%$ when compared with untreated CR [36]. Recently, Strukar et al. [103] recommended carrying research for structural applications of rubberized concrete concerning the limitation of rubber contents and methodology for pre-treatment of rubber aggregates. Li et al. [36] recommended the scope of further research to find the cost-effective and most efficient method of bond improvement, which is important concerning its field application. It was 
also suggested to do further research to investigate the durability of rubberized concrete with modified rubber surfaces.

Researchers have explored approaches such as chemical pre-treatment of scrap tires as a means of reducing the mechanical strength loss in rubberized cement composites. Li et al. [104] pre-coated the rubber particles with cement paste before being applied in concrete production. The energy-absorbing capability of the samples was found to increase with the added CR particles. Balaha et al. [105] reported that the use of polyvinyl alcohol $(\mathrm{PVA})$ and sodium hydroxide $(\mathrm{NaOH})$ treated $\mathrm{CR}$ reduced the compressive and tensile strength loss observed in these concrete mixes compared to mixes containing untreated CR. The $\mathrm{NaOH}$ treatment enhances the adhesion of tire rubber particles to cement paste, abrasion resistance and water absorption experiments [106]. CR mostly heavily aged during the service life and the ageing effect can attach functional groups (e.g., the carboxylic acids group) to the $\mathrm{CR}$ particle. After the treatment with $\mathrm{NaOH}$, the acid carboxylic group will react with the alkaline content and during cement hydration, the chemical structure can provide a weak basic condition near the rubber aggregate-cement interface which will enhance ITZ properties. But in general, this method complicates the technology of concrete production, indeed it affects the hardening chemistry of the binder but does not give significant results.

Dong et al. [107] verify the feasibility of the approach [108] to improve the performance of CRC through developing a cementitious coating around rubber particles with a silane coupling agent. The results showed that the compressive and split tensile strengths of concrete incorporating coated rubber were 10-20\% higher than the concrete incorporating uncoated rubber. Albano et al. [109] also observed an insignificant improvement in the compressive and splitting tensile strengths of rubberized concrete containing silane pretreated scrap tire waste as a fine aggregate replacement material.

Rubber particles have been added to cement to form a self-healing cement system, where the rubber particles can expand on exposure to a particular fluid to close cracks, improving the sealing performances of the cement [110,111].

Improvement in the compressive, tensile and flexural strengths of concrete samples containing waste tire pre-treated with sulphur compounds was reported by Chou et al. [112]. Using a UV based pre-treatment on the CR has been shown to reduce strength losses [113]. For the pre-coating CR, water and $3 \mu \mathrm{m}$ limestone powder were mixed in a Hobart mixer at a low speed [46]. He et al. [114] in their paper excavated the engineering application potential of rubberized concrete by using urea solution which could be beneficial for application in $\mathrm{CRC}$ to improve the mechanical strength and impact resistance. However, it is well-known that urea $\left(\mathrm{CO}\left(\mathrm{NH}_{2}\right)_{2}\right)$, a chemical compound that provides reagents for calcium carbonate formation, is already among the most used precursors being added to the biological culture medium for some decades [115-117]. Biel and Lee [74] experimented with a special cement Magnesium Oxychloride type to enhance the bonding strength between rubber particles and cement. Regarding the different grinding processes of the CR (mechanical or cryogenic), even though there is a small difference in compressive strength in favour of cryogenic $C R$, there is no significant benefit to favour one or the other (furthermore, cryogenic CR is more expensive) [86].

It has recently been suggested that tire rubber ash can also be used to enhance concrete microstructure [56]. Combining surface treatment and particle size reduction might produce Portland cement concrete that can be used in varieties of applications. Reducing the particle size down to the same order of magnitude of cement powders will both reduce the "flaw" induced by the recycling and increase the stiffness of the particles. Enhanced pre-treatment of the rubber surface and mixing minerals can improve the strength of CRC [46]. However, surface treatment does have the potential to help improve the bond, it will not change the fundamental fact of the stiffness incompatibility between the $\mathrm{CR}$ and other constituents of Portland cement concrete. 


\subsection{Usage of Supplementary Cementitious Materials (SCMs) along with CR in Concrete}

The use of supplementary cementitious materials (SCMs) such as silica fume (10\% [118], $15 \%$ [101]), fly ash and metakaolin can slightly enhance the mechanical properties of CRC. Guneyisi et al. [119] believe that silica fume helps mostly the adherence between rubber aggregates and the binder because of the small size of the CR particles. Azevedo et al. [120] reported that a CRC mix containing 30\% SCMs (15\% fly ash $+15 \%$ metakaolin) exhibited a $23 \%$ reduction in compressive strength in comparison to the reference samples. Onuaguluchi and Panesar [46] indicated a clear correlation in the minimization of concrete strength loss and resistance to chloride penetration when silica fume was used as a bonding agent in conjunction with CR content. Such concrete mixes would be highly suitable for marine environment structures, which are more susceptible to accelerated deterioration due to corrosion-causing chlorides. Furthermore, [121] observed an increase in the abrasion resistance and compressive strength of rubberized concrete with the addition of silica fume.

\subsection{CR Application in High-Performance Concrete}

The brittle failure of the control high-performance concrete and non-brittle failure of CRC highlights an increase in the ductile nature when fine aggregates are partly replaced with CR [122]. CR application in high-performance concrete may be limited by the effects of increased replacement levels. The CRC containing $0-12.5 \%$ CR can be an optimal replacement level which could indicate a successful usage within high strength concrete mixes [12]. The addition of silica fume as a bonding agent to CRC with $C R$ replacement level up to $12.5 \%$ can be beneficial to exhibit minimal losses in compressive, flexural tensile, and pull-off strengths, as well as an increase in abrasion resistance and water penetration, and a decrease in water absorption [14]. The addition of super-absorbent polymers (SAPs) to CRC can improve the pore size distribution and pore connectivity to have a positive impact on the internal self-drying effect during hydration and its volume stability for concrete with low $\mathrm{w} / \mathrm{c}$ ratios [123].

\subsection{Durability}

Freeze-thaw action is the major reason for the cracking of concrete and ageing of concrete structures. The addition of CR can effectively enhance the concrete freeze-thaw resistance [124-126]. Richardson et al. [127] indicated that a C40 (40 MPa) concrete mixture containing $0.6 \% \mathrm{CR}$ by weight of concrete displayed optimal durability factors when $\mathrm{CR}$ models exhibited minimal internal and surface damage throughout 56 freeze-thaw cycles; contrasting with reference concrete models that demonstrated failure after 28 cycles. Si et al. [128] demonstrated that the added CR can lead to a lower mass loss and dynamic modulus decrease after 500 freeze-thaw cycles. The enhancement of the freeze-thaw resistance is caused by the fact that the ductile CR can provide extra space for ice expansion and increase the air void content [129]. The provided extra space by CR can be also favourable for the expansion of the alkali-silica reaction (ASR) gel due to swelling. Afshinnia and Poursaee [130] examined the ASR expansion of mortar samples with $16 \%$ and $24 \%$ replaced CR, ASR expansion of the samples decreased by $43 \%$ and $39 \%$, respectively.

A higher percentage of $C R$ aggregates in concrete causes an increase in water absorption. Several researchers $[43,131,132]$ observed an increase in the immersed water absorption of concrete with the incorporation of CR. In contrast, Segre et al. [133] and Oikonomou and Mavridou [134] reported reductions in the absorbed water of rubberized cement composites as the CR content of mixes increased. Depth of water penetration was observed to increase by $0 \%$ to $225 \%$ compared to reference concrete when CR contents were increased by $2.5 \%$ to $20 \%$ [135]. The presence of CR aggregate in concrete shows encouraging behaviour for abrasion resistance too [135]. Appropriate content and size of $\mathrm{CR}$, and pre-treatment of $\mathrm{CR}$ results in enhanced abrasion resistance of rubberized concrete.

Drying shrinkage in concrete commonly increases with the addition of CR aggregates [136]. It has been observed that the free shrinkage increases because of strain capacity enhancement when $<4 \mathrm{~mm}$ crumb rubber aggregate replacement is used. It has been 
suggested that this incremental change in shrinkage could be due to the incorporation of the low stiffness aggregate (i.e., rubber particles) leading to a reduction in 'internal restraint' and a consequent increase in the length change resulting from shrinkage [137]. However, it was decreased when rubber aggregates were pre-treated with sodium hydro-oxide solution [128]. It was because of improved adhesion between cement matrix and rubber aggregates.

It was observed that prolonged exposure to chloride ions and higher $\mathrm{CR}$ contents causes to increase in its penetration depth [138]. For small rubber contents (about $5 \%$ to $12.5 \%$ ), chloride ion penetration in rubberized concrete is normally reduced. However, it has reverse behavior when rubber content is more than $12.5 \%$ [135]. The CRC sample with $\mathrm{NaOH}$ treated $\mathrm{CR}$ have higher chloride resistance [139].

Incorporating $\mathrm{CR}$ can alter the fine pore pressure of the concrete and the degree of corrosion of the inner steel of the concrete can be reduced [140]. Thomas et al. [135] indicated the carbonation depth will not increase within the $12.5 \%$ rubber replacement ratio. However, Bravo and de Brito [132] demonstrated the carbonation depth will increase with the $\mathrm{CR}$ replacement ratio. The influence of added $\mathrm{CR}$ on concrete carbonation resistance is controversial.

Concrete is deteriorated by acid attack and may disintegrate due to reaction with alkaline ingredients during the hydration process in concrete. However, rubberized concrete exhibits high acid resistance. Reference concrete exhibited greater loss of weight at 90 and 180 days in $3 \% \mathrm{H}_{2} \mathrm{SO}_{4}$ solution. However, it was decreased with a rise in rubber aggregate contents [13]. The durability of CRC is significantly affected by sulphate attack [135]. Loss of mass is generally taken as an evaluation factor to check the resistance of rubberized concrete against sulphate attack. Carbonation depth was observed to be decreased by $38 \%$ to $15 \%$ upon adding $10 \%$ to $25 \%$ of CR powder in samples of mortar having a $0.56 \mathrm{w} / \mathrm{c}$ ratio. In opposite to that, carbonation depth was increased by $44 \%$ to $200 \%$ with the addition of CR powder by $5 \%$ to $25 \%$ in mortar samples having a $0.51 \mathrm{w} / \mathrm{c}$ ratio [141].

\subsection{Leaching and Ecotoxicology}

Most studies mentioned above were mostly focused on the mechanical and durability properties but less on ecotoxicological and leaching issues for CRC. The potential ecotoxicological impact of $C R$ remains largely unknown but has been recognized as an information gap that needs to be addressed.

The application of CR in concrete production can lead to environmental concerns due to the presence of trace metals and polycyclic aromatic hydrocarbons (PAHs) [142]. However, the surrounding cementitious materials can well confine the trace metals or volatile organics exited in rubber particles based on the Toxicity Characteristic Leaching Procedure (TCLP) test [143].

$\mathrm{Zn}$ is often cited as the candidate most likely responsible for observed CRG/tire wear particles (TWP) leachate toxicity $[1,15]$. $\mathrm{Zn}$ is used in tires as a vulcanization activator by manufacturers, and zinc leachate is believed to contribute predominantly to the leachate toxicity within the surrounding environment. For example, zinc toxicity was shown to be related to a disruption of calcium ion uptake in Daphnia magna [144]. The presence of $\mathrm{Zn}$ in the highest concentrations doesn't necessarily indicate the highest risk of toxicity since there are other chemicals present in CR which can contribute to toxicity at the lower concentrations [1].

Several publications originated from the US tried to bring attention to the toxicological side of the CRG application problem about the reuse of disposal tires. The crumb rubber material (CRM) has been widely used as in fill for artificial turf installations in the US since 1960. Concerns have been expressed that those metals, including manganese (Mn), iron $(\mathrm{Fe})$ and $\mathrm{Zn}$ derived from tire rubber could be transferred to the environment and affect organisms having direct contact with recycled products, tire wear particles or illegal dumps. For example, chemical additives such as $\mathrm{Zn}$ and PAHs were widely detected in the leachate from tire rubber [145-148]. Zhang et al. [147] reported that the levels of PAHs and 
$\mathrm{Zn}$ in CR used as infill for artificial turf were above health-based soil standards, and lead $(\mathrm{Pb})$ in the CRM was highly bioaccessible in synthetic gastric fluid at relatively low levels. The leaching from CRG is assumed to occur more rapidly due to the increased surface area when compared to whole tires. The toxic leaching occurs from an equivalent source and poses an increasing threat to the environment, indicating that CRG particulates and the leaching chemicals will continue to pose a threat to wildlife long after their disposal $[1,149]$. The leaching test based on the TCLP standard demonstrated that the concentration of the leached $\mathrm{Zn}$ can exceed the limit and can lead to potential pollution [150]. Kardos and Durham [143] conducted the TCLP test to examine the leaching potential of the concrete prepared with $\mathrm{CR}$ particles and the results demonstrated the concentration of both leached trace metals and volatile organics were below the limit. Compared to dense cement concrete materials, the confinement in asphalt concrete material is relatively limited, for example. Field tests of the asphalt pavement with CRM demonstrated the leached concentration of Benzothiazole, 2(3H)-benzothiazolone, mercury $(\mathrm{Hg})$ and aluminium $(\mathrm{Al})$ reached potential harmful levels [151]. Benzothiazole (BT) and its derivatives, derived primarily from tire wear particles, were detected ubiquitously in environmental samples [152,153].

The $\mathrm{pH}$ level can significantly influence the leaching potential of both trace metals and hydrocarbons. The study [154] demonstrated that organics and metals can be more easily leached out under basic and acid conditions, respectively. Similarly, the study by Selbes et al. [155] also demonstrated that trace metals can be more easily extracted from CR under acidic conditions and the amount of dissolved organic carbon (DOC) was significantly increased under basic conditions. Another factor that can influence the leaching potential is the ageing effect of the waste organic component; however, the influence is still not very clear.

Besides the environmental impact caused by the production of raw materials and handling of demolition waste, it must be considered that potentially harmful substances can be leached from the materials during their service life because of their exposure to water in the form of rain, surface water or groundwater. Trace metals can also be leached out which can originate from natural or secondary raw materials or additives as well as from primary and secondary fuels used in the production process of cement [156]. Their release is dependent on different factors, e.g., the chemical composition of the leachate [157] and the binding mechanisms of the substances [158].

To date, several European countries including Belgium, Germany and The Netherlands carry out investigations concerning the release of potentially harmful substances from hardened concrete. The first standard — the tank test, NEN 7345 [159]—was developed in 1995 in the Netherlands and was revised in 2004 as NEN7375 [160]. The corresponding German method was published by the German Committee for Reinforced Concrete (DAfStb) in 2005 as a guideline [161]. A harmonized European technical specification, the DSLT, was published in 2014 [21]. Currently, leaching is tested according to the Flemish Standard CMA 2/II/A.9.1 [162] in Belgium. According to the test procedures (commonly used: column and diffusion tests) the usual set of determining compounds are: sulphate (SO4), chloride $(\mathrm{Cl})$, bromide $(\mathrm{Br})$, fluoride $(\mathrm{F})$, arsenic $(\mathrm{As})$, barium $(\mathrm{Ba})$, cadmium $(\mathrm{Cd})$, cobalt $(\mathrm{Co})$, chromium $(\mathrm{Cr}), \mathrm{Cu}$, molybdenum (Mo), nickel (Ni), $\mathrm{Pb}$, antimony $(\mathrm{Sb})$, selenium (Se), tin (Sn), vanadium (V) and $\mathrm{Zn})$. However, there is a certain concern that crushed powder can accelerate the leaching and does not reflect reality. The comparison of leaching criteria is given in $[159,162]$ and for some trace metals it is shown in Table 1. In the USA, the EPA method 1315 [163] is used to evaluate the leaching behavior of monolithic materials and compacted granular materials. In these tests, pre-stored hardened concrete samples are exposed to deionized water with periodic renewal of the water. The renewal times and the liquid-to-surface area ratio differ between the test methods. For the evaluation of the DSLT results, limits for the cumulative release are defined in Germany [164] and the Netherlands [165]. All the standardized tests are intended to be performed on hardened materials only. However, for some applications, concrete may be exposed to water already in a fresh state during the construction phase. At the beginning of hydration, there is no 
phase boundary between the water and the fresh cement paste, and soluble substances are not yet fixed in the hydration products. Therefore, it can be assumed that cementitious materials show a different leaching behavior in the fresh state and the leaching of the fresh material should be investigated separately [156].

Table 1. Comparison of leaching criteria.

\begin{tabular}{|c|c|c|c|c|}
\hline & $\begin{array}{c}\text { Shaped } \\
\text { Applications NEN } \\
7345\left(\mathrm{mg} / \mathrm{m}^{2}\right)\end{array}$ & $\begin{array}{l}\text { Belgium (Flanders) } \\
\text { Non-Shaped } \\
\text { Applications CMA } \\
\text { 2/II/A.9.1 (mg/kg } \\
\text { d.s.) }\end{array}$ & $\begin{array}{c}\text { Shaped } \\
\text { Applications NEN } \\
7345\left(\mathrm{mg} / \mathrm{m}^{2}\right)\end{array}$ & $\begin{array}{c}\text { The Netherlands } \\
\text { Non-Shaped } \\
\text { Applications NEN } \\
7345\left(\mathrm{mg} / \mathrm{m}^{2}\right)\end{array}$ \\
\hline $\mathrm{Cd}$ & 1.1 & 0.03 & 3.8 & 0.04 \\
\hline $\mathrm{Cu}$ & 25 & 0.8 & 98 & 0.9 \\
\hline $\mathrm{Pb}$ & 60 & 1.3 & 400 & 2.3 \\
\hline $\mathrm{Zn}$ & 90 & 2.8 & 800 & 4.5 \\
\hline
\end{tabular}

\subsection{Recycling of $C R C$}

All over the globe the construction industry takes 50\% of raw materials from nature, consumes $40 \%$ of total energy and produces $50 \%$ of total waste [166]. The approach 'concrete to concrete' in general preserves the natural aggregates and solves the problem of reducing the space and energy required for the landfill disposal of concrete waste. Recycled concrete aggregate (RCA) as such, holds original aggregate with hydrated cement paste. RCA are available in size of $20 \mathrm{~mm}$ to $50 \mathrm{~mm}$; finer fractions also are available. The density of RCA is normally lower than the density of natural aggregate. The main reason for the lower density is that the adhered mortar is lighter in weight compared to the same volume of natural aggregate, which decreases the density. The density of RCA is not constant for all the crushed concrete aggregate. It depends upon the specific aggregate. The shape and gradation of RCA are dependent on the production method and type of crusher used for the manufacturing of RCA. Recycled concrete as aggregates is relatively weaker in strength as compared to natural aggregates. The crushing and abrasion value of RCA is also lower than the natural aggregates. If several SCMs are used in concrete mix design which normally are meant for cement replacement, improvement of certain properties, there is a possibility that RCA has a positive effect on the concrete properties [167]. It can be mentioned that the recycling of CRC aggregates should not be a problem when CR is a part of the hardened cement matrix.

\section{Discussion}

The outcome of the current state-of-the-art review and performed research so far shows certain gaps that prevent a complete overview of mechanical behavior and environmental impact (leaching behavior, ecotoxicology, and recyclability) of CRC to object to the stereotypes which prevent to use CR in concrete in the construction industry. The four major barriers can be distinguished for a successful CR application in the concrete industry: (1) the cost of CR recycling, (2) mechanical properties reduction, (3) insufficient research about leaching criteria and ecotoxicological risks and (4) recyclability of CRC.

Recycling a large number of organic aggregates into concrete can be developed for reduced environmental impacts and natural resources. There is a certain deficiency of river sand in Belgium, which lately was partly replaced by crushed limestone. During the past years, a shift has been observed within the concrete sector from the use of river sand from The Netherlands and/or Germany to Belgian marine sand. At present, about 3 million tons or 2 million $\mathrm{m}^{3}$ of Belgian marine sands is extracted each year, of which $80 \%$ is used in the construction industry [168]. The mining and quarry industry should guarantee an adequate and continuous supply of raw materials as a producer of construction minerals to the construction sector to sustain the economic development of the country [169]. The effect of a shortage of these construction materials results in increased construction cost and then 
transferring the burden to the end-users, which in turn affects the national development. Aggressive consumption reduces the non-renewable aggregate resources; therefore, proper planning and prevention are essential to avoid the impact of shortage and address the issues that may affect the supply for future development. All stakeholders involved in the construction industry need to start shifting towards production methods adopted by a sustainability model to maintain security and preserve the long-term availability of construction mineral supplies. One of the best ways suggested is the practice of the mandate for a sustainable concept through recycling activities in the construction and/or concrete industries.

Several actions should take place to bring CRC to the market. CR surface treatment (that leads to interface bonding between CR and cement paste), and concrete mix design optimization need to be properly developed for each type of CR application in concrete for possible field applications (see Section 2.1). The production of high-performance concrete containing CR needs to be added as the normal practice [5]. The cost analysis among various surface treatment methods must be thoroughly studied and the cost-effectiveness of different types of CRC and CRC construction elements production must be provided.

It is usually considered that the price of processed CR is higher than natural aggregates and might not be price-wise reasonable for application in concrete. However, if to consider the landfilling cost of waste rubber tires [170] and processed CR (mechanically ground) cost [171] for the application in concrete, there might be a contradiction in opinions (see Tables 2 and 3).

Table 2. Sand prices for application in concrete.

\begin{tabular}{ccccc}
\hline $\begin{array}{c}\text { Volume } \\
\left(\mathbf{m}^{\mathbf{3}}\right)\end{array}$ & $\begin{array}{c}\text { Price of Sand }(\boldsymbol{\epsilon}) \\
{[\mathbf{1 7 2}]}\end{array}$ & Sand Mass $\mathbf{( k g )}$ & \multicolumn{3}{c}{ Sand in Certain Concrete Mix [92] } \\
Price of Sand $(\boldsymbol{\epsilon})$ & Price of Sand (15\%) $(\boldsymbol{\epsilon})$ \\
\hline 1 & 139 & 770 & 71.35 & $\mathbf{1 0 . 7 0}$ \\
10 & 265 & 7700 & 136.03 & $\mathbf{2 0 . 4 1}$ \\
20 & 405 & 15,400 & 207.90 & $\mathbf{3 1 . 1 9}$ \\
50 & 825 & 38,500 & 423.50 & $\mathbf{6 3 . 5 3}$ \\
100 & 1525 & 77,000 & 782.83 & $\mathbf{1 1 7 . 4 3}$ \\
\hline
\end{tabular}

Table 3. Processed CR (15\%) price vs. sand (15\%) in CRC.

\begin{tabular}{|c|c|c|c|c|c|c|c|}
\hline \multirow{2}{*}{$\begin{array}{l}\text { Volume } \\
\left(\mathrm{m}^{3}\right)\end{array}$} & \multirow{2}{*}{$\begin{array}{c}\text { Price of CR } \\
(15 \%)(€)[171]\end{array}$} & \multicolumn{2}{|c|}{ Landfill Tax (15\%) (€) } & \multicolumn{2}{|c|}{$\begin{array}{l}\text { Price of CR (15\%) Incl. Possible } \\
\text { Landfill Tax (€) }\end{array}$} & \multicolumn{2}{|c|}{$\begin{array}{c}\text { Difference in Price CR } \\
\text { vs. Sand }(€)\end{array}$} \\
\hline & & Flanders & Wallonia & Flanders & Wallonia & Flanders & Wallonia \\
\hline 1 & 4.86 & 4.08 & 4.54 & 0.79 & 0.32 & -9.92 & -10.38 \\
\hline 10 & 48.64 & 40.78 & 45.44 & 7.86 & 3.20 & -12.55 & -17.21 \\
\hline 20 & 97.28 & 81.56 & 90.89 & 15.72 & 6.39 & -15.47 & -24.79 \\
\hline 50 & 243.20 & 203.91 & 227.22 & 39.29 & 15.98 & -24.23 & -47.55 \\
\hline 100 & 486.4 & 407.82 & 454.44 & 78.58 & 31.96 & -38.84 & -85.47 \\
\hline
\end{tabular}

It has been already pointed out by Kazmi et al. [11] that incorporated landfill tax of waste tires in CRC cost calculations is assumed to be part of a processed CR cost, and hence, the cost of CR is considered zero.

In Table 3, the possible difference in cost when 15\% of CR (mechanically ground) is used in concrete to replace $15 \%$ of sand (in Belgium, incl. Flanders and Wallonia regions) is shown. The approximate price for sand is given considering that $1 \mathrm{~m}^{3}$ is about $1500 \mathrm{~kg}$, however the final sand price can be higher depending on the region of delivery [172]. If to consider that the final price of CR consists of actual processed CR price minus possible landfill tax, then CR (mechanically ground) application in concrete benefits with a sand replacement for $15 \%$.

CRC still need to be tested and modelled in detail before it can be widely used in construction [75]. However, the UniSA (Australia), RMIT University (Australia) and University of Salerno (Italy) researchers consider that the role of CRC may not need to be limited to structures that are less dependent on strength. In several studies $[24,26,27,37,61,173,174]$, 
they have shown that a wide variety of techniques in the CRC production processes can be used to improve its structural properties.

\section{Conclusions}

The application of $\mathrm{CR}$ in concrete has certainly its advantages and in general, cannot be ignored by the construction industry. CR can be applied, for example, as an alternative material to replace natural aggregates and CRC can be used as RCA in the future. A certain diversity for the CR application can be introduced in a more efficient way when CR surface treatment and concrete mix design optimization are properly developed for each type of $\mathrm{CR}$ application in concrete for possible field applications. The role of CRC should not be limited to structures that are less dependent on strength:

- The workability of rubberized concrete decreases with the increase in CR content and particle size. However, it can be improved with the inclusion of admixtures such as superplasticizers, silica fume, SCMs like fly ash, slagand metakaolin.

- The density of rubberized concrete decreases substantially with the increase in CR content or fineness, due to the lower specific gravity and air-entraining capability of CR. This makes rubberized concrete useful for lightweight structures.

- The pre-treatment of CR influences positively on ITZ. If the bond is improved at ITZ by any suitable and economical means then the negative effects of $C R$ on strength properties of normal concrete may be reduced, consequently, it would be possible to effectively use the rubberized concrete in numerous concrete structures by the construction industry.

- The optimal CR replacement range based on the mechanical, physical and durability properties could vary between $10-20 \%$ for fine aggregates replacement and $5 \%$ for coarse aggregates replacement.

- Within the optimal range and pre-treatment of CR: (1) freeze-thaw resistance, chloride ion penetration resistance, acid resistance and abrasion resistance are enhanced; (2) ASR, drying shrinkage and carbonation will not increase. However, CRC is significantly affected by sulphate attacks.

- The incorporation of $\mathrm{CR}$ significantly improves the dampness ratio of concrete. The vibration absorption capacity and increased dampness absorption make CRC an ideal construction material in structures under dynamic load including railways sleepers, seismic prone structures, concrete columns, bridges etc.

- It has been confirmed the surrounding cementitious materials can well confine the trace metals or volatile organics exited in rubber particles based on the TCLP test.

- The cost analysis among various surface treatment methods must be thoroughly studied and the cost-effectiveness of different types of CRC and CRC construction elements production must be provided.

Author Contributions: Writing—original draft preparation, P.K.D.M.; writing—review, J.B., L.B. and B.C. All authors have read and agreed to the published version of the manuscript.

Funding: This research received no external funding.

Institutional Review Board Statement: This study does not involve any studies on humans or animals. Informed Consent Statement: Not applicable.

Conflicts of Interest: The authors declare no conflict of interest.

\section{References}

1. Halsband, C.; Sørensen, L.; Booth, A.M.; Herzke, D. Car tire crumb rubber: Does leaching produce a toxic chemical cocktail in coastal marine systems? Front. Environ. Sci. 2020, 8, 125. [CrossRef]

2. Song, W.-J.; Qiao, W.-G.; Yang, X.-X.; Lin, D.-G.; Li, Y.-Z. Mechanical properties and constitutive equations of crumb rubber mortars. Constr. Build. Mater. 2018, 172, 660-669. [CrossRef]

3. Seddik Meddah, M. Recycled aggregates in concrete production: Engineering properties and environmental impact. MATEC Web Conf. 2017, 101, 05021. [CrossRef] 
4. Su, H.; Yang, J.; Ling, T.-C.; Ghataora, G.S.; Dirar, S. Properties of concrete prepared with waste tyre rubber particles of uniform and varying sizes. J. Clean. Prod. 2015, 91, 288-296. [CrossRef]

5. Guo, S.; Hu, J.; Dai, Q. A critical review on the performance of portland cement concrete with recycled organic components. J. Clean. Prod. 2018, 188, 92-112. [CrossRef]

6. SMART. Final Report Summary-SMART (Sustainable Moulding of Articles from Recycled Tyres). Available online: https: / / cordis.europa.eu/project/id/286465/reporting (accessed on 29 April 2021).

7. ANAGENNISI. Final Report Summary-ANAGENNISI (Innovative Reuse of All Tyre Components in Concrete). Available online: https:/ / cordis.europa.eu/project/id/603722 (accessed on 29 April 2021).

8. RISEN. Periodic Reporting for Period 1-RISEN (Rail Infrastructure systems Engineering Network). Available online: https: / / cordis.europa.eu/project/id/691135/reporting (accessed on 29 April 2021).

9. ARC Linkage Project. Reinforced crumbed Rubber Concrete for Residential Construction. Available online: https: //www.unisa.edu.au/research/scarce-resources-and-circular-economy/research-projects/reinforced-crumbed-rubberconcrete-for-residential-construction/ (accessed on 29 April 2021).

10. Leal Filho, W.; Hunt, J.; Lingos, A.; Platje, J.; Vieira, L.W.; Will, M.; Gavriletea, M.D. The unsustainable use of sand: Reporting on a global problem. Sustainability 2021, 13, 3356. [CrossRef]

11. Kazmi, S.M.S.; Munir, M.J.; Wu, Y.-F. Application of waste tire rubber and recycled aggregates in concrete products: A new compression casting approach. Resour. Conserv. Recy. 2021, 167, 105353. [CrossRef]

12. Sofi, A. Effect of waste tyre rubber on mechanical and durability properties of concrete-A review. Ain Shams Eng. J. 2018, 9, 2691-2700. [CrossRef]

13. Bisht, K.; Ramana, P.V. Waste to resource conversion of crumb rubber for production of sulphuric acid resistant concrete. Constr. Build. Mater. 2019, 194, 276-286. [CrossRef]

14. Thomas, B.S.; Gupta, R.C.; Panicker, V.J. Recycling of waste tire rubber as aggregate in concrete: Durability-related performance. J. Clean. Prod. 2016, 112, 504-513. [CrossRef]

15. Wagner, S.; Hüffer, T.; Klöckner, P.; Wehrhahn, M.; Hofmann, T.; Reemtsma, T. Tire wear particles in the aquatic environment-A review on generation, analysis, occurrence, fate and effects. Water Res. 2018, 139, 83-100. [CrossRef]

16. Sienkiewicz, M.; Kucinska-Lipka, J.; Janik, H.; Balas, A. Progress in used tyres management in the European Union: A review. Waste Manag. 2012, 32, 1742-1751. [CrossRef]

17. Lapkovskis, V.; Mironovs, V.; Kasperovich, A.; Myadelets, V.; Goljandin, D. Crumb rubber as a secondary raw material from waste rubber: A short review of end-of-life mechanical processing methods. Recycling 2020, 5, 32. [CrossRef]

18. ETRMA. European Tyre and Rubber Industry—Statistics; ETRMA: Brussels, Belgium, 2014.

19. Directive 1999/31/EC of 26 April 1999 on the Landfill of Waste, EUR-Lex, Publications Office of the European Union, Luxembourg, Luxembourg. Available online: https: / / eur-lex.europa.eu/legal-content/EN/TXT/?uri=CELEX\%3A01999L0031-20180704\&qid= 1626971916106 (accessed on 22 July 2021).

20. Directive 2008/98/EC of the European Parliament and of the Council of 19 November 2008 on Waste and Repealing Certain Directives, EUR-Lex, Publications Office of the European Union, Luxembourg, Luxembourg. Available online: https:/ / eur-lex. europa.eu/legal-content/EN/TXT/?uri=CELEX\%3A32008L0098\&qid=1626973255571 (accessed on 22 July 2021).

21. PD CEN/TS16637-2:2014. Construction Products_Assessment of Release of Dangerous Substances_Part 2: Horizontal Dynamic Surface Leaching Test; CEN-CENELEC Management Centre: Brussels, Belgium, 2014.

22. Pilakoutas, K.; Neocleous, K.; Tlemat, H. Reuse of tyre steel fibres as concrete reinforcement. Proc. Inst. Civ. Eng. 2004, 157, 131-138. [CrossRef]

23. Neocleous, K.; Tlemat, H.; Pilakoutas, K. Design issues for concrete reinforced with steel fibers, including fibers recovered from used tires. J. Mater. Civil. Eng. 2006, 18, 677-685. [CrossRef]

24. Aiello, M.A.; Leuzzi, F.; Centonze, G.; Maffezzoli, A. Use of steel fibres recovered from waste tyres as reinforcement in concrete: Pull-out behaviour, compressive and flexural strength. Waste Manag. 2009, 29, 1960-1970. [CrossRef]

25. Barros, J.A.; Zamanzadeh, Z.; Mendes, P.J.; Lourenço, L. Assessment of the potentialities of recycled steel fibres for the reinforcement of cement based materials. In Proceedings of the 3rd Workshop: The New Boundaries of Structural Concrete, Session C-New Scenarios for Concrete, ACI Italy Chapter, Bergamo, Italy, 3-4 October 2013; pp. 1-11.

26. Caggiano, A.; Xargay, H.; Folino, P.; Martinelli, E. Experimental and numerical characterization of the bond behavior of steel fibers recovered from waste tires embedded in cementitious matrices. Cem. Concr. Comp. 2015, 62, 146-155. [CrossRef]

27. Martinelli, E.; Caggiano, A.; Xargay, H. An experimental study on the post-cracking behaviour of Hybrid Industrial/Recycled Steel Fibre-Reinforced Concrete. Constr. Build. Mater. 2015, 94, 290-298. [CrossRef]

28. Onuaguluchi, O.; Banthia, N. Durability performance of polymeric scrap tire fibers and its reinforced cement mortar. Mater. Struct. 2017, 50, 158. [CrossRef]

29. Medina, N.F.; Medina, D.F.; Hernández-Olivares, F.; Navacerrada, M.A. Mechanical and thermal properties of concrete incorporating rubber and fibres from tyre recycling. Constr. Build. Mater. 2017, 144, 563-573. [CrossRef]

30. Chen, M.; Chen, W.; Zhong, H.; Chi, D.; Wang, Y.; Zhang, M. Experimental study on dynamic compressive behaviour of recycled tyre polymer fibre reinforced concrete. Cem. Concr. Comp. 2019, 98, 95-112. [CrossRef]

31. Siddique, R.; Naik, T.R. Properties of concrete containing scrap-tire rubber-An overview. Waste Manag. 2004, $24,563-569$. [CrossRef] 
32. Papakonstantinou, C.G.; Tobolski, M.J. Use of waste tire steel beads in Portland cement concrete. Cem. Concr. Res. 2006, 36, 1686-1691. [CrossRef]

33. Khaloo, A.R.; Dehestani, M.; Rahmatabadi, P. Mechanical properties of concrete containing a high volume of tire-rubber particles. Waste Manag. 2008, 28, 2472-2482. [CrossRef] [PubMed]

34. Ganjian, E.; Khorami, M.; Maghsoudi, A.A. Scrap-tyre-rubber replacement for aggregate and filler in concrete. Constr. Build. Mater. 2009, 23, 1828-1836. [CrossRef]

35. Aiello, M.A.; Leuzzi, F. Waste tyre rubberized concrete: Properties at fresh and hardened state. Waste Manag. 2010, 30, 1696-1704. [CrossRef]

36. Li, Y.; Zhang, S.; Wang, R.; Dang, F. Potential use of waste tire rubber as aggregate in cement concrete-A comprehensive review Constr. Build. Mater. 2019, 225, 1183-1201. [CrossRef]

37. Barros, J.A.O.; Frazão, C.; Caggiano, A.; Folino, P.; Martinelli, E.; Xargay, H.; Zamanzadeh, Z.; Lourenço, L. Cementitious composites reinforced with recycled fibres. In Recent Advances on Green Concrete for Structural Purposes: The Contribution of the EU-FP7 Project EnCoRe; Barros, J.A.O., Ferrara, L., Martinelli, E., Eds.; Springer: Cham, Switzerland, 2017; pp. 141-195. [CrossRef]

38. Khatib, Z.K.; Bayomy, F.M. Rubberized Portland cement concrete. J. Mater. Civil. Eng. 1999, 11, 206-213. [CrossRef]

39. Aslani, F.; Khan, M. Properties of high-performance self-compacting rubberized concrete exposed to high temperatures. J. Mater. Civil. Eng. 2019, 31, 04019040. [CrossRef]

40. Kaloush, K.E.; Way, G.B.; Zhu, H. Properties of crumb rubber concrete. Transp. Res. Rec. 2005, 1914, 8-14. [CrossRef]

41. Yang, L.-H.; Han, Z.; Li, C.-F. Strengths and flexural strain of CRC specimens at low temperature. Constr. Build. Mater. 2011, 25, 906-910. [CrossRef]

42. Loderer, C.; Partl, M.N.; Poulikakos, L.D. Effect of crumb rubber production technology on performance of modified bitumen. Constr. Build. Mater. 2018, 191, 1159-1171. [CrossRef]

43. Mohammed, B.S.; Anwar Hossain, K.M.; Eng Swee, J.T.; Wong, G.; Abdullahi, M. Properties of crumb rubber hollow concrete block. J. Clean. Prod. 2012, 23, 57-67. [CrossRef]

44. Yung, W.H.; Yung, L.C.; Hua, L.H. A study of the durability properties of waste tire rubber applied to self-compacting concrete. Constr. Build. Mater. 2013, 41, 665-672. [CrossRef]

45. Rashad, A.M. A comprehensive overview about recycling rubber as fine aggregate replacement in traditional cementitious materials. Int. J. Built Environ. Sustain. 2016, 5, 46-82. [CrossRef]

46. Onuaguluchi, O.; Panesar, D.K. Hardened properties of concrete mixtures containing pre-coated crumb rubber and silica fume. J. Clean. Prod. 2014, 82, 125-131. [CrossRef]

47. Najim, K.B.; Hall, M.R. Crumb rubber aggregate coatings/pre-treatments and their effects on interfacial bonding, air entrapment and fracture toughness in self-compacting rubberised concrete (SCRC). Mater. Struct. 2013, 46, 2029-2043. [CrossRef]

48. Hamdi, A.; Abdelaziz, G.; Farhan, K.Z. Scope of reusing waste shredded tires in concrete and cementitious composite materials: A review. J. Build. Eng. 2021, 35, 102014. [CrossRef]

49. Zheng, L.; Sharon Huo, X.; Yuan, Y. Experimental investigation on dynamic properties of rubberized concrete. Constr. Build. Mater. 2008, 22, 939-947. [CrossRef]

50. Youssf, O.; Hassanli, R.; Mills, J.E.; Abd Elrahman, M. An experimental investigation of the mechanical performance and structural application of LECA-Rubcrete. Constr. Build. Mater. 2018, 175, 239-253. [CrossRef]

51. Zhang, B.; Poon, C.S. Sound insulation properties of rubberized lightweight aggregate concrete. J. Clean. Prod. 2018, 172, 3176-3185. [CrossRef]

52. Kashani, A.; Ngo, T.D.; Mendis, P.; Black, J.R.; Hajimohammadi, A. A sustainable application of recycled tyre crumbs as insulator in lightweight cellular concrete. J. Clean. Prod. 2017, 149, 925-935. [CrossRef]

53. El-Gammal, A.; Abdel-Gawad, A.K.; El-Sherbini, Y.; Shalaby, A. Compressive strength of concrete utilizing waste tire rubber. J. Eng. Trends Eng. Appl. Sci. 2010, 1, 96-99. [CrossRef]

54. Bignozzi, M.C.; Sandrolini, F. Tyre rubber waste recycling in self-compacting concrete. Cem. Concr. Res. 2006, 36, 735-739. [CrossRef]

55. Najim, K.B.; Hall, M.R. A review of the fresh/hardened properties and applications for plain-(PRC) and self-compacting rubberised concrete (SCRC). Constr. Build. Mater. 2010, 24, 2043-2051. [CrossRef]

56. Reda Taha, M.M.; El-Dieb, A.S.; Abd El-Wahab, M.A.; Abdel-Hameed, M.E. Mechanical, fracture, and microstructural investigations of rubber concrete. J. Mater. Civil. Eng. 2008, 20, 640-649. [CrossRef]

57. Uygunoğlu, T.; Topçu, İ.B. The role of scrap rubber particles on the drying shrinkage and mechanical properties of selfconsolidating mortars. Constr. Build. Mater. 2010, 24, 1141-1150. [CrossRef]

58. Mohammadi, I.; Khabbaz, H. Shrinkage performance of crumb rubber concrete (CRC) prepared by water-soaking treatment method for rigid pavements. Cem. Concr. Comp. 2015, 62, 106-116. [CrossRef]

59. Meddah, A.; Beddar, M.; Bali, A. Use of shredded rubber tire aggregates for roller compacted concrete pavement. J. Clean. Prod. 2014, 72, 187-192. [CrossRef]

60. Rahman, M.M.; Usman, M.; Al-Ghalib, A.A. Fundamental properties of rubber modified self-compacting concrete (RMSCC). Constr. Build. Mater. 2012, 36, 630-637. [CrossRef]

61. Youssf, O.; ElGawady, M.A.; Mills, J.E. Static cyclic behaviour of FRP-confined crumb rubber concrete columns. Eng. Struct. 2016, 113, 371-387. [CrossRef] 
62. Medina, N.F.; Garcia, R.; Hajirasouliha, I.; Pilakoutas, K.; Guadagnini, M.; Raffoul, S. Composites with recycled rubber aggregates: Properties and opportunities in construction. Constr. Build. Mater. 2018, 188, 884-897. [CrossRef]

63. Al-Tayeb, M.M.; Abu Bakar, B.H.; Akil, H.M.; Ismail, H. Performance of rubberized and hybrid rubberized concrete structures under static and impact load conditions. Exp. Mech. 2013, 53, 377-384. [CrossRef]

64. Al-Tayeb, M.M.; Abu Bakar, B.H.; Ismail, H.; Akil, H.M. Effect of partial replacement of sand by recycled fine crumb rubber on the performance of hybrid rubberized-normal concrete under impact load: Experiment and simulation. J. Clean. Prod. 2013, 59, 284-289. [CrossRef]

65. Li, W.; Huang, Z.; Wang, X.C.; Wang, J.W. Review of crumb rubber concrete. Appl. Mech. Mater. 2014, 672-674, 1833-1837. [CrossRef]

66. Xu, X.; Zhang, Z.; Hu, Y.; Wang, X. Bearing strength of crumb rubber concrete under partial area loading. Materials 2020, 13, 2446. [CrossRef]

67. Duarte, A.P.C.; Silva, B.A.; Silvestre, N.; de Brito, J.; Júlio, E.; Castro, J.M. Finite element modelling of short steel tubes filled with rubberized concrete. Compos. Struct. 2016, 150, 28-40. [CrossRef]

68. Frankowski, R. Patent US 5290356 Rubber Crumb-Reinforced Cement Concrete. U.S. Patent 5290356, 23 April 1992.

69. Eldin, N.N.; Senouci, A.B. Observations on rubberized concrete behavior. Cem. Concr. Comp. 1994, 16, 287-298. [CrossRef]

70. Zandi, I.; Lepore, J.; Rostami, H. Particulate rubber included concrete compositions. U.S. Patent 5456751, 14 November 1994.

71. Topçu, İ.B. The properties of rubberized concretes. Cem. Concr. Res. 1995, 25, 304-310. [CrossRef]

72. Fattuhi, N.I.; Clark, L.A. Cement-based materials containing shredded scrap truck tyre rubber. Constr. Build. Mater. 1996, 10, 229-236. [CrossRef]

73. Toutanji, H.A. The use of rubber tire particles in concrete to replace mineral aggregates. Cem. Concr. Comp. 1996, 18, 135-139. [CrossRef]

74. Biel, T.D.; Lee, H. Magnesium oxychloride cement concrete with recycled tire rubber. Transp. Res. Rec. 1996, 1561, 6-12. [CrossRef]

75. Mills, J.; Gravina, R.; Zhuge, Y.; Ma, X.; Skinner, B. Crumbed Rubber Concrete: A Promising Material for Sustainable Construction. 2018. Available online: https://www.scientia.global/wp-content/uploads/Mills-Zhuge-Skinner-Ma-Gravina/Mills-ZhugeSkinner-Ma-Gravina.pdf (accessed on 1 February 2021).

76. Li, Y.; Zhang, X.; Wang, R.; Lei, Y. Performance enhancement of rubberised concrete via surface modification of rubber: A review. Constr. Build. Mater. 2019, 227, 116691. [CrossRef]

77. Topçu, İ.B. Assessment of the brittleness index of rubberized concretes. Cem. Concr. Res. 1997, 27, 177-183. [CrossRef]

78. Li, C.-F.; Xie, J.; Liu, C.; Guo, S.; Deng, J. Fire performance of high-strength concrete reinforced with recycled rubber particles. Mag. Concr. Res. 2011, 63, 187-195. [CrossRef]

79. Hassanli, R.; Youssf, O.; Mills, J.E. Experimental investigations of reinforced rubberized concrete structural members. J. Build. Eng. 2017, 10, 149-165. [CrossRef]

80. Ling, T.-C. Prediction of density and compressive strength for rubberized concrete blocks. Constr. Build. Mater. 2011, 25, 4303-4306. [CrossRef]

81. Eldin, N.N.; Senouci, A.B. Rubber-tire particles as concrete aggregate. J. Mater. Civil. Eng. 1993, 5, 478-496. [CrossRef]

82. Issa, C.A.; Salem, G. Utilization of recycled crumb rubber as fine aggregates in concrete mix design. Constr. Build. Mater. 2013, 42, 48-52. [CrossRef]

83. Liu, F.; Zheng, W.; Li, L.; Feng, W.; Ning, G. Mechanical and fatigue performance of rubber concrete. Constr. Build. Mater. 2013, 47, 711-719. [CrossRef]

84. Yang, G.; Chen, X.; Xuan, W.; Chen, Y. Dynamic compressive and splitting tensile properties of concrete containing recycled tyre rubber under high strain rates. Sädhanā 2018, 43, 178. [CrossRef]

85. Chan, C.W.; Yu, T.; Zhang, S.S.; Xu, Q.F. Compressive behaviour of FRP-confined rubber concrete. Constr. Build. Mater. 2019, 211, 416-426. [CrossRef]

86. Valadares, F.; Bravo, M.; de Brito, J. Concrete with used tire rubber aggregates: Mechanical performance. ACI Mater. J. 2012, 109, 283-292.

87. da Silva, F.M.; Gachet Barbosa, L.A.; Lintz, R.C.C.; Jacintho, A.E.P.G.A. Investigation on the properties of concrete tactile paving blocks made with recycled tire rubber. Constr. Build. Mater. 2015, 91, 71-79. [CrossRef]

88. Jokar, F.; Khorram, M.; Karimi, G.; Hataf, N. Experimental investigation of mechanical properties of crumbed rubber concrete containing natural zeolite. Constr. Build. Mater. 2019, 208, 651-658. [CrossRef]

89. Ismail, M.K.; Hassan, A.A.A. Impact resistance and mechanical properties of self-consolidating rubberized concrete reinforced with steel fibers. J. Mater. Civil. Eng. 2017, 29, 04016193. [CrossRef]

90. Bharathi Murugan, R.; Natarajan, C. Investigation of the behaviour of concrete containing waste tire crumb rubber. In Advances in Structural Engineering; Matsagar, V., Ed.; Springer: New Delhi, India, 2015; pp. 1795-1802. [CrossRef]

91. Wu, Y.-F.; Kazmi, S.M.S.; Munir, M.J.; Zhou, Y.; Xing, F. Effect of compression casting method on the compressive strength, elastic modulus and microstructure of rubber concrete. J. Clean. Prod. 2020, 264, 121746. [CrossRef]

92. Van Tigchelt, S.; Roelandt, D.; Kara De Maeijer, P.; Craeye, B. Use of Crumb Rubber as Inert Material for Sustainable Concrete Applications. Master's Thesis, UAntwerp, Antwerpen, Belgium, 2021.

93. Ganesan, N.; Bharati Raj, J.; Shashikala, A.P. Flexural fatigue behavior of self compacting rubberized concrete. Constr. Build. Mater. 2013, 44, 7-14. [CrossRef] 
94. Güneyisi, E. Fresh properties of self-compacting rubberized concrete incorporated with fly ash. Mater. Struct. 2010, 43, 1037-1048. [CrossRef]

95. Lotfy, A.; Hossain, K.M.A.; Lachemi, M. Mix design and properties of lightweight self-consolidating concretes developed with furnace slag, expanded clay and expanded shale aggregates. J. Sustain. Cem. Based Mater. 2016, 5, 297-323. [CrossRef]

96. Ismail, M.K.; Hassan, A.A.A. Use of metakaolin on enhancing the mechanical properties of self-consolidating concrete containing high percentages of crumb rubber. J. Clean. Prod. 2016, 125, 282-295. [CrossRef]

97. Alsaif, A.; Bernal, S.A.; Guadagnini, M.; Pilakoutas, K. Freeze-thaw resistance of steel fibre reinforced rubberised concrete. Constr. Build. Mater. 2019, 195, 450-458. [CrossRef]

98. Youssf, O.; Mills, J.E.; Hassanli, R. Assessment of the mechanical performance of crumb rubber concrete. Constr. Build. Mater. 2016, 125, 175-183. [CrossRef]

99. Bekhiti, M.; Trouzine, H.; Asroun, A. Properties of waste tire rubber powder. Eng. Technol. Appl. Sci. Res. 2014, 4, 669-672. [CrossRef]

100. Gregori, A.; Castoro, C.; Marano, G.C.; Greco, R. Strength reduction factor of concrete with recycled rubber aggregates from tires J. Mater. Civil. Eng. 2019, 31, 04019146. [CrossRef]

101. Pelisser, F.; Zavarise, N.; Longo, T.A.; Bernardin, A.M. Concrete made with recycled tire rubber: Effect of alkaline activation and silica fume addition. J. Clean. Prod. 2011, 19, 757-763. [CrossRef]

102. Mohammadi, I.; Khabbaz, H.; Vessalas, K. Enhancing mechanical performance of rubberised concrete pavements with sodium hydroxide treatment. Mater. Struct. 2016, 49, 813-827. [CrossRef]

103. Strukar, K.; Kalman Šipoš, T.; Miličević, I.; Bušić, R. Potential use of rubber as aggregate in structural reinforced concrete element-A review. Eng. Struct. 2019, 188, 452-468. [CrossRef]

104. Li, Z.; Li, F.; Li, J.S.L. Properties of concrete incorporating rubber tyre particles. Mag. Concr. Res. 1998, 50, 297-304. [CrossRef]

105. Balaha, M.M.; Badawy, A.A.M.; Hashish, M. Effect of using ground waste tire rubber as fine aggregate on the behaviour of concrete mixes. Indian J. Eng. Mater. Sci. 2007, 14, 427-435. Available online: http://nopr.niscair.res.in/bitstream/123456789/22 5/1/IJEMS\%2014\%286\%29\%20\%282007\%29\%20427-435.pdf (accessed on 1 February 2021).

106. Segre, N.; Joekes, I. Use of tire rubber particles as addition to cement paste. Cem. Concr. Res. 2000, 30, 1421-1425. [CrossRef]

107. Dong, Q.; Huang, B.; Shu, X. Rubber modified concrete improved by chemically active coating and silane coupling agent. Constr. Build. Mater. 2013, 48, 116-123. [CrossRef]

108. Huang, B.; Shu, X.; Cao, J. A two-staged surface treatment to improve properties of rubber modified cement composites. Constr. Build. Mater. 2013, 40, 270-274. [CrossRef]

109. Albano, C.; Camacho, N.; Reyes, J.; Feliu, J.L.; Hernández, M. Influence of scrap rubber addition to Portland I concrete composites: Destructive and non-destructive testing. Compos. Struct. 2005, 71, 439-446. [CrossRef]

110. Cavanagh, P.H.; Johnson, C.R.; Roy-Delage, L.; Sylvaine, D.; Gerard, G.; Cooper, I.; Guillot, D.J.; Bulte, H.; Dargaud, B. Self-healing cement-novel technology to achieve leak-free wells. In Proceedings of the SPE/IADC Drilling Conference, Amsterdam, The Netherlands, 20-22 February 2007. [CrossRef]

111. Le Roy-Delage, S.; Comet, A.; Garnier, A.; Presles, J.L.; Bulté-Loyer, H.; Drecq, P.; Rodriguez, I.U. Self-healing cement system-A step forward in reducing long-term environmental impact. In Proceedings of the IADC/SPE Drilling Conference and Exhibition, New Orleans, LA, USA, 2-4 February 2010. [CrossRef]

112. Chou, L.-H.; Lin, C.-N.; Lu, C.-K.; Lee, C.-H.; Lee, M.-T. Improving rubber concrete by waste organic sulfur compounds. Waste Manag. Res. 2010, 28, 29-35. [CrossRef] [PubMed]

113. Ossola, G.; Wojcik, A. UV modification of tire rubber for use in cementitious composites. Cem. Concr. Comp. 2014, 52, 34-41. [CrossRef]

114. He, L.; Cai, H.; Huang, Y.; Ma, Y.; Van den bergh, W.; Gaspar, L.; Valentin, J.; Vasiliev, Y.E.; Kowalski, K.J.; Zhang, J. Research on the properties of rubber concrete containing surface-modified rubber powders. J. Build. Eng. 2021, 35, 101991. [CrossRef]

115. Mwaluwinga, S.; Ayano, T.; Sakata, K. Influence of urea in concrete. Cem. Concr. Res. 1997, 27, 733-745. [CrossRef]

116. Stocks-Fischer, S.; Galinat, J.K.; Bang, S.S. Microbiological precipitation of $\mathrm{CaCO}_{3}$. Soil Biol. Biochem. 1999, $31,1563-1571$. [CrossRef]

117. De Muynck, W.; Debrouwer, D.; De Belie, N.; Verstraete, W. Bacterial carbonate precipitation improves the durability of cementitious materials. Cem. Concr. Res. 2008, 38, 1005-1014. [CrossRef]

118. Gesoğlu, M.; Güneyisi, E. Strength development and chloride penetration in rubberized concretes with and without silica fume. Mater. Struct. 2007, 40, 953-964. [CrossRef]

119. Güneyisi, E.; Gesoğlu, M.; Özturan, T. Properties of rubberized concretes containing silica fume. Cem. Concr. Res. 2004, 34, 2309-2317. [CrossRef]

120. Azevedo, F.; Pacheco-Torgal, F.; Jesus, C.; Barroso de Aguiar, J.L.; Camões, A.F. Properties and durability of HPC with tyre rubber wastes. Constr. Build. Mater. 2012, 34, 186-191. [CrossRef]

121. Kang, J.; Zhang, B.; Li, G. The abrasion-resistance investigation of rubberized concrete. J. Wuhan Univ. Technol. Mat. Sci. Edit. 2012, 27, 1144-1148. [CrossRef]

122. Mohajerani, A.; Burnett, L.; Smith, J.V.; Markovski, S.; Rodwell, G.; Rahman, M.T.; Kurmus, H.; Mirzababaei, M.; Arulrajah, A.; Horpibulsuk, S.; et al. Recycling waste rubber tyres in construction materials and associated environmental considerations: A review. Resour. Conserv. Recy. 2020, 155, 104679. [CrossRef] 
123. Zhu, H.; Wang, Z.; Xu, J.; Han, Q. Microporous structures and compressive strength of high-performance rubber concrete with internal curing agent. Constr. Build. Mater. 2019, 215, 128-134. [CrossRef]

124. Gonen, T. Freezing-thawing and impact resistance of concretes containing waste crumb rubbers. Constr. Build. Mater. 2018, 177, 436-442. [CrossRef]

125. Shu, X.; Huang, B. Recycling of waste tire rubber in asphalt and portland cement concrete: An overview. Constr. Build. Mater. 2014, 67, 217-224. [CrossRef]

126. Girskas, G.; Nagrockienė, D. Crushed rubber waste impact of concrete basic properties. Constr. Build. Mater. 2017, 140, 36-42. [CrossRef]

127. Richardson, A.E.; Coventry, K.A.; Ward, G. Freeze/thaw protection of concrete with optimum rubber crumb content. J. Clean. Prod. 2012, 23, 96-103. [CrossRef]

128. Si, R.; Guo, S.; Dai, Q. Durability performance of rubberized mortar and concrete with NaOH-Solution treated rubber particles. Constr. Build. Mater. 2017, 153, 496-505. [CrossRef]

129. Thomas, B.S.; Chandra Gupta, R. Properties of high strength concrete containing scrap tire rubber. J. Clean. Prod. 2016, 113, 86-92. [CrossRef]

130. Afshinnia, K.; Poursaee, A. The influence of waste crumb rubber in reducing the alkali-silica reaction in mortar bars. J. Build. Eng. 2015, 4, 231-236. [CrossRef]

131. Gesoğlu, M.; Güneyisi, E. Permeability properties of self-compacting rubberized concretes. Constr. Build. Mater. 2011, 25, 3319-3326. [CrossRef]

132. Bravo, M.; de Brito, J. Concrete made with used tyre aggregate: Durability-related performance. J. Clean. Prod. 2012, 25, 42-50. [CrossRef]

133. Segre, N.; Joekes, I.; Galves, A.D.; Rodrigues, J.A. Rubber-mortar composites: Effect of composition on properties. J. Mater. Sci. 2004, 39, 3319-3327. [CrossRef]

134. Oikonomou, N.; Mavridou, S. Improvement of chloride ion penetration resistance in cement mortars modified with rubber from worn automobile tires. Cem. Concr. Comp. 2009, 31, 403-407. [CrossRef]

135. Thomas, B.S.; Gupta, R.C. Long term behaviour of cement concrete containing discarded tire rubber. J. Clean. Prod. 2015, 102, 78-87. [CrossRef]

136. Alsaif, A.; Koutas, L.; Bernal, S.A.; Guadagnini, M.; Pilakoutas, K. Mechanical performance of steel fibre reinforced rubberised concrete for flexible concrete pavements. Constr. Build. Mater. 2018, 172, 533-543. [CrossRef]

137. Turatsinze, A.; Bonnet, S.; Granju, J.L. Potential of rubber aggregates to modify properties of cement based-mortars: Improvement in cracking shrinkage resistance. Constr. Build. Mater. 2007, 21, 176-181. [CrossRef]

138. Alsaif, A.; Bernal, S.A.; Guadagnini, M.; Pilakoutas, K. Durability of steel fibre reinforced rubberised concrete exposed to chlorides. Constr. Build. Mater. 2018, 188, 130-142. [CrossRef]

139. Guo, S.; Dai, Q.; Si, R.; Sun, X.; Lu, C. Evaluation of properties and performance of rubber-modified concrete for recycling of waste scrap tire. J. Clean. Prod. 2017, 148, 681-689. [CrossRef]

140. Zhu, H.; Liang, J.; Xu, J.; Bo, M.; Li, J.; Tang, B. Research on anti-chloride ion penetration property of crumb rubber concrete at different ambient temperatures. Constr. Build. Mater. 2018, 189, 42-53. [CrossRef]

141. Gheni, A.A.; Alghazali, H.H.; ElGawady, M.A.; Myers, J.J.; Feys, D. Durability properties of cleaner cement mortar with by-products of tire recycling. J. Clean. Prod. 2019, 213, 1135-1146. [CrossRef]

142. Li, X.; Berger, W.; Musante, C.; Mattina, M.I. Characterization of substances released from crumb rubber material used on artificial turf fields. Chemosphere 2010, 80, 279-285. [CrossRef]

143. Kardos, A.J.; Durham, S.A. Strength, durability, and environmental properties of concrete utilizing recycled tire particles for pavement applications. Constr. Build. Mater. 2015, 98, 832-845. [CrossRef]

144. Muyssen, B.T.A.; De Schamphelaere, K.A.C.; Janssen, C.R. Mechanisms of chronic waterborne Zn toxicity in Daphnia magna. Aquat. Toxicol. 2006, 77, 393-401. [CrossRef] [PubMed]

145. Stephensen, E.; Adolfsson-Erici, M.; Celander, M.; Hulander, M.; Parkkonen, J.; Hegelund, T.; Sturve, J.; Hasselberg, L.; Bengtsson, M.; Förlin, L. Biomarker responses and chemical analyses in fish indicate leakage of polycyclic aromatic hydrocarbons and other compounds from car tire rubber. Environ. Toxicol. Chem. 2003, 22, 2926-2931. [CrossRef]

146. Wik, A.; Dave, G. Environmental labeling of car tires-toxicity to Daphnia magna can be used as a screening method. Chemosphere 2005, 58, 645-651. [CrossRef]

147. Zhang, J.; Han, I.-K.; Zhang, L.; Crain, W. Hazardous chemicals in synthetic turf materials and their bioaccessibility in digestive fluids. J. Expo. Sci. Environ. Epidemiol. 2008, 18, 600-607. [CrossRef]

148. Kanematsu, M.; Hayashi, A.; Denison, M.S.; Young, T.M. Characterization and potential environmental risks of leachate from shredded rubber mulches. Chemosphere 2009, 76, 952-958. [CrossRef]

149. Turner, A.; Rice, L. Toxicity of tire wear particle leachate to the marine macroalga, Ulva lactuca. Environ. Pollut. 2010, 158, 3650-3654. [CrossRef]

150. Bocca, B.; Forte, G.; Petrucci, F.; Costantini, S.; Izzo, P. Metals contained and leached from rubber granulates used in synthetic turf areas. Sci. Total Environ. 2009, 407, 2183-2190. [CrossRef]

151. Azizian, M.F.; Nelson, P.O.; Thayumanavan, P.; Williamson, K.J. Environmental impact of highway construction and repair materials on surface and ground waters: Case study: Crumb rubber asphalt concrete. Waste Manag. 2003, 23, 719-728. [CrossRef] 
152. Reddy, C.M.; Quinn, J.G. Environmental chemistry of benzothiazoles derived from rubber. Environ. Sci. Technol. 1997, 31, 2847-2853. [CrossRef]

153. Kloepfer, A.; Jekel, M.; Reemtsma, T. Determination of benzothiazoles from complex aqueous samples by liquid chromatographymass spectrometry following solid-phase extraction. J. Chromatogr. A 2004, 1058, 81-88. [CrossRef]

154. Downs, L.A.; Humphrey, D.N.; Katz, L.E.; Rock, C.A. Water Quality Effects of Using Tire Chips below the Groundwater Table. University of Maine, Orono, ME, USA. 1996. Available online: https://www.ustires.org/sites/default/files/LEA_004_USTMA. pdf (accessed on 18 July 2021).

155. Selbes, M.; Yilmaz, O.; Khan, A.A.; Karanfil, T. Leaching of DOC, DN, and inorganic constituents from scrap tires. Chemosphere 2015, 139, 617-623. [CrossRef] [PubMed]

156. Overmann, S.; Lin, X.; Vollpracht, A. Investigations on the leaching behavior of fresh concrete-A review. Constr. Build. Mater. 2021, 272, 121390. [CrossRef]

157. Hartwich, P.; Vollpracht, A. Influence of leachate composition on the leaching behaviour of concrete. Cem. Concr. Res. 2017, 100, 423-434. [CrossRef]

158. Vollpracht, A.; Brameshuber, W. Binding and leaching of trace elements in Portland cement pastes. Cem. Concr. Res. 2016, 79, 76-92. [CrossRef]

159. NEN7345. Uitloogkarakteristieken-Bepaling van de Uitloging van Anorganische Componenten uit Vormgegeven en Monolitische Materialen met een Diffusieproef_Vaste Grond-en Steenachtige Materialen; The Royal Netherlands Standardization Institute: Delft, The Netherlands, 1995. (In Dutch)

160. NEN7375. Leaching Characteristics-Determination of the Leaching of Inorganic Components from Moulded or Monolitic Materials with a Diffusion Test-Solid Earthy and Stony Materials; The Royal Netherlands Standardization Institute: Delft, The Netherlands, 2004.

161. DAfStb. Determination of the Release of Inorganic Substances Byleaching from Cement-Bound Building Materials; Deutscher Ausschuss für Stahlbeton: Berlin, Germany, 2005.

162. CMA2/II/A.9.1. VLAREMA-The Flemish Standard. 2016. Available online: https://navigator.emis.vito.be/mijn-navigator? woId=43993 (accessed on 1 March 2021).

163. SW-846. Test Method 1315. Mass Transfer Rates of Constituents in Monolithic or Compacted Granular Materials Using a Semi-Dynamic Tank Leaching Procedure; United States Environmental Protection Agency (EPA): Washington, DC, USA, 2017.

164. Deutsches Institut für Bautechnik (DIBt). Muster-Verwaltungsvorschrift Technische Baubestimmungen; Model Administrative Regulation Fortechnical Building Regulations; Deutsches Institut für Bautechnik: Berlin, Germany, 2019. (In German)

165. Dutch Soil Quality Decree: Regulation of 13 December 2007, No. DJZ2007124397. Available online: https://wetten.overheid.nl/ BWBR0023085/2018-11-30 (accessed on 18 July 2021). (In Dutch)

166. Oikonomou, N.D. Recycled concrete aggregates. Cem. Concr. Comp. 2005, 27, 315-318. [CrossRef]

167. Kara, P. The next generation ecological self compacting concrete with glass waste powder as a cement component in concrete and recycled concrete aggregates. In Proceedings of the 3rd Workshop on The New Boundaries of Structural Concrete, University of Bergamo-ACI Italy Chapter, Bergamo, Italy, 3-4 October 2013; pp. 21-30, ISBN 9788890429279.

168. FPSE, Sand and Gravel Extractionin the Belgian Part of the North Sea. Federal Public Service Economy, SMEs, Self-Employed and Energy. 2014. Available online: www.vliz.be/imisdocs/publications/265503.pdf (accessed on 30 April 2021).

169. Ismail, S.; Hoe, K.W.; Ramli, M. Sustainable aggregates: The potential and challenge for natural resources conservation. Procedia Soc. Behav. Sci. 2013, 101, 100-109. [CrossRef]

170. CEWEP, Landfill Taxes and Bans Overview. Available online: https://www.cewep.eu/wp-content/uploads/2017/12/Landfilltaxes-and-bans-overview.pdf (accessed on 30 April 2021).

171. RECYTYRE, Recytyre in Sprekende Cijfers. Available online: https:/ /www.recytyre.be/nl/recytyre-sprekende-cijfers (accessed on 30 April 2021). (In Dutch)

172. Wat Kost een Kuub Zand. Available online: https://grondverzet.nu/wat-kost-een-kuub-zand (accessed on 30 April 2021). (In Dutch)

173. Youssf, O.; ElGawady, M.A.; Mills, J.E.; Ma, X. An experimental investigation of crumb rubber concrete confined by fibre reinforced polymer tubes. Constr. Build. Mater. 2014, 53, 522-532. [CrossRef]

174. Youssf, O.; Hassanli, R.; Mills, J.E. Mechanical performance of FRP-confined and unconfined crumb rubber concrete containing high rubber content. J. Build. Eng. 2017, 11, 115-126. [CrossRef] 